\title{
Nutrient intakes and adequacy among preschool children under blockade in Gaza City, Palestine
}

\author{
Samir $\operatorname{Radi}^{1}$
}

${ }^{1}$ Health Management Information Unit, Ministry of Health, Gaza, Palestine (Correspondence to: Samir Radi: samir_radi@hotmail.com).

\begin{abstract}
Background: After 13 years of blockade and closure, malnutrition has become a significant risk to the health of Gaza's youngest residents. According to recent national surveys, Palestinians are facing a double burden of malnutrition and very low levels of essential minerals and vitamins.
\end{abstract}

Aims: The aims of this study were to assess nutrient intake adequacy among preschool children and to estimate the dietary and nutrient intake deficiency in the Gaza Strip.

Methods: This cross-sectional, community-based, household survey was carried out in Gaza using 24-hour dietary recall to assess nutrient intake and adequacy among 176 children aged 2-5 years.

Results: Based on the nutrient deficiency for dietary intake $[<75 \%$ recommended dietary allowance (RDA)], energy shows the highest level of deficiency $(89.8 \%)$ in the diet among the studied children followed by vitamin A intake (86.9\%). About three quarters $(73.3 \%)$ of the children studied consumed less than the RDA for calcium and $47.2 \%$ consumed less than the RDA for iron. Approximately $20 \%$ of the children consumed less than the RDA level of dietary intake for carbohydrate and $17 \%$ for zinc.

Conclusion: Nutrient intake among preschoolers in the Gaza Strip shows a dramatic deterioration in macro- and micronutrient deficiency, especially in rural areas. Although the findings in this study are in line with previous reports, it revealed greater deterioration than previous local studies.

Keywords: nutrient intake, preschool children,, recommended dietary allowance, Palestine

Citation: Radi S. Nutrient intakes and adequacy among preschool children under blockade in Gaza City, Palestine. East Mediterr Health J. 2021;27(5):467473. https://doi.org/10.26719/2021.27.5.467

Received: 27/11/19; accepted: 04/08/20

Copyright (C) World Health Organization (WHO) 2021. Open Access. Some rights reserved. This work is available under the CC BY-NC-SA 3.o IGO license (https://creativecommons.org/licenses/by-nc-sa/3.o/igo)

\section{Introduction}

The Gaza Strip is divided into 5 governorates, North Gaza, Gaza City, Deir Al Balah, Khan Yunis, and Rafah. The localities have been classified into 3 types: urban, rural, and camp (1). Gaza City has one refugee camp (Al-Shati Refugee Camp), one rural area (Al-Moghraga) and the rest of the districts in the city are considered urban areas.

Living conditions in Gaza are deteriorating at an alarming and unprecedented rate. Record high levels of unemployment have compounded the widespread prevalence of poverty, significantly reducing people's purchasing power and further restricting their access to food (2). The coping strategies of the most vulnerable population in Gaza revealed an inappropriate diet in terms of variety and daily intake. Only $14 \%$ of children under 5 years of age had the minimum acceptable diet (3).

The blockade and 3 major escalations of hostilities over recent years have increased frustration and exacerbated the vulnerability of the 2 million Palestinians living in the Gaza Strip. Chronic power deficits disrupt basic services such as education, health, nutrition and water, sanitation and hygiene (4). Since the blockade and closure, malnutrition has become a significant risk to the health of Gaza's youngest residents (5). Decades of occupation in the West Bank coupled with a ten-year old blockade and slow recovery in Gaza following the 2014 war have been undermining the living conditions of Palestinians. The recurrent violence and economic stagnation, has further exacerbated vulnerabilities and the capacity of poor Palestinians to access sufficient quantities of nutritious food (6). Gaza has the highest unemployment rate in the world: youth unemployment topped6o\% in 2017. Nearly $80 \%$ of the population is dependent on international aid (7).

According to recent national surveys, Palestinians are facing a double burden of malnutrition: a high level of micronutrient deficiencies alongside growing overweight and obesity. Approximately 50\% of the people assessed had very low levels of essential minerals and vitamins. Depleted iron levels were found in $28 \%$ in the Gaza Strip. According to the World Health Organization (WHO) standards, anaemia among children in Gaza Strip is a moderate public health problem (8).

The purpose of this study was to assess the adequacy of nutrient intakes among preschool children in the Gaza Strip, Palestine. The study objectives include the assessment of the child's macro- and micronutrient intake and to estimate dietary and nutrient intake deficiency by age and locality. 


\section{Methods}

\section{Sampling}

This community-based, cross-sectional study was conducted during the first half of 2018 in Gaza City. The sample included urban, rural and refugee camp children aged 2-5 years. We used a multistage, stratified, cluster sampling technique with probability proportionate to the size of the population in the first stage and a constant number of children per cluster in the second stage. The sampling frame was Gaza City. It was divided into 12 primary sampling units, 7 of which (Al-Shati Ref Refugee Camp, Al-Moghraga rural area, Al-Sheikh Radwan, Al-Shagaia, Al-Sabra, Al-Zitoon and Al-Twfah) were randomly selected for this study.

The sample size was calculated by assuming the prevalence rate of deficiency at 50\%, a confidence interval of $95 \%$, a precision of $5 \%$ and design effect of 2 . By using a systematic random sampling methods for a subsample (every fifth household) where a certain number of households (selected randomly in the field) were visited and used to express the actual sample size of the study that computed at 25 children from each area, with total actual sample size at 175 children, with one eligible child selected from every household.

The quota sampling method was used with a fixed number of children in each area. From each of the 7 areas, 25 children were selected. The data collecting teams kept selecting households in the cluster until the specified number of children was reached, regardless of the number of households visited. The teams had a target number of children to reach, so where there were no children in a household, they skipped that and visited the neighbouring household.

Accordingly, 25 households were selected from each area, with one child selected from each household giving a total of 175 . However, in one household 2 children of the relevant age were selected, giving an actual sample size of 176 children with a response rate of $100 \%$.

\section{Dietary intake questionnaires}

A pre-designed structured interview questionnaire was used to assess the dietary intake pattern of the children. A quantitative dietary intake questionnaire of the 24hour diet recall was used to assess the child's quantitative dietary intake (9). Three teams carried out the data collection; each team comprised 2 qualified nurses. All the teams had good previous experience in filling out the 24 hour-food recall questionnaire. The child's food intake was collected by asking the mother about the quantities of food consumed during the previous day for main meals and snacks.

In line with ethical research principles, the interviewed mothers received a complete explanation of the study and a consent form for the optional decision to participate in the study.

The 24-hour diet recall methodology was based on the food intake booklet developed and modified by Al-
Quds University, with pictures of Palestinian dishes that varied in volume, size, and weight, and common Middle Eastern recipes. The adapted methodology was based on the food intake booklet of the United States Department of Agriculture (10).

The daily intake (grams) from the different food items and groups was computed for all 176 preschoolers in the sample using the food intake booklet. The energy and energy-yielding nutrient content of the diet as well as selected micronutrients were defined by quantity based on the 2006 food composition table for Egypt to obtain the mean daily nutrient intake (11).

Protein, fat and iron were classified according to animal and vegetable sources in data management. Energy, measured by calorie consumption, and the macronutrient protein, fat and carbohydrate were computed in grams, while the micronutrients calcium, iron and zinc were computed in milligrams, except for vitamin $\mathrm{A}$, which was computed in micrograms of retinol ( $\mu \mathrm{g}$ RE).The recommended dietary allowance (RDA) for each macro- or micronutrient indicated by the American Food and Nutrition Board were used as the reference for the percentage nutrient intake deficiency below $75 \%$ of the RDA (12).

- The ratios for animal protein, animal fat and animal iron to total protein, fat and iron intake were calculated.

- Energy, and macro- and micronutrient adequacy intake were defined by dividing the estimated intake of each child by the RDA for each age group and computed by locality.

- Dietary quality was calculated from the proportion of energy coming from animal food sources and the mean dietary quality was estimated.

- The mean nutrient density for protein, fat and carbohydrate out of the total energy intake for each age group was estimated.

\section{Statistical analysis}

Data entry, management and analysis were performed using SPSS, version 20.0. Data were checked for data entry errors and validated by checking for valid response categories. Frequency distribution was generated for all variables and for quantitative variables, mean $( \pm S D)$ was calculated. Independent-samples t-test to compare the mean differences in daily intake of macro- and micronutrients between age groups was used. For all analyses, statistical significance was set at $P<0.05$.

\section{Results}

\section{Localities}

The total sample was 176 children, 96 (55\%) boys and 80 (45\%) girls. The sample was collected from 7 districts $(3$ types of locality) in Gaza City: one rural area (Al-Moghraga), one refugee camp (Al Shata) and 5 urban districts. The sample ages were: 114 children aged $2-<4$ years and 
62 children aged 4-5 years, with mean age 42.4 (SD 10.2) months.

\section{Child's nutrient intake}

\section{Macro and micronutrient consumption}

Daily intake for energy, carbohydrate, total protein, total fat and animal fat consumption were statistically significantly higher among the older age group (Table 1). Total mean daily energy intake was 908.3 (SD 224.9) kcal, with the older age group children consuming significantly more energy than the younger age group [971.0 (SD 220.5) vs 874.3 (SD 220.9) kcal; $t=2.77, P=0.006$ ]. The total daily carbohydrate intake was 127.9 (SD 32.0) $\mathrm{g}$ for the whole sample, with the older age group consuming significantly more carbohydrate than the younger age group [135.5 (SD 30.9) vs 123.8 (SD 31.9) $\mathrm{g} ; \mathrm{t}=2.34, P=0.020$ ].

The total daily protein consumption was 29.2 (SD 8.5) $\mathrm{g}$, with the older age group consuming significantly more protein [31.2 (SD 8.2) vs 28.1 (SD 8.5) g, $t=2.33, P=0.013$ ) than the younger age group (Table 1). The total daily fat intake was 31.1 (SD 12.6) g, with the older age group consuming significantly more fat than the younger age group [33.8 (SD 12.8) g vs 29.6 (SD 12.4) $\mathrm{g},=2.12, P=0.035$ ] The total mean animal fat intake was 11.8 (SD 8.7) g, with the older age group consuming significantly more animal fat than the younger age group [13.7 (SD 9.3) $\mathrm{g}$ vs 10.8 (SD 8.2) $\mathrm{g}, \mathrm{t}=2.15, P=0.032]$.

Other micro- and macronutrients showed similar results, with the older age group consuming slightly greater amounts, except for calcium where the younger children consumed slightly more than the older ones. However none of these differences was statistically significant (Table 1)

\section{Nutrient density of the consumed diet}

Mean protein density ratio was 13.0 (SD 3.0) in the consumed diet, with the fat density ratio 30.0 (SD 8.3) and the carbohydrate density ratio 56.9 (SD 8.7) (Table 2). The protein and fat density ratios in the younger age group were almost the same as in the older age group while the carbohydrate density was slightly higher (57.3 (SD 9.1) vs 56.3 (SD 8.1).

\section{Adequacy of the consumed diet}

\section{Macro and micronutrient deficiency}

Table 3 describes the proportion of children in the sample whose dietary intake for a given nutrient was less than $75 \%$ of the RDA, thus defining the extent of macro- and micronutrient deficiency for the targeted preschool children.

The highest levels of deficiency ( $<75 \%$ of RDA) among the preschool children in this study were seen for energy, vitamin A and calcium. Overall, energy deficiency was $89.8 \%$; greater deficiency was seen in the diet of the older children $(93.5 \%)$ than the younger age group $(87.7 \%)$. For vitamin A intake, overall deficiency was $86.9 \%$, slightly higher among the older children. Just over $73 \%$ of the children consumed $<75 \%$ of the RDA for calcium in their

\begin{tabular}{|c|c|c|c|c|c|c|c|c|}
\hline \multirow[t]{3}{*}{ Nutrient } & \multicolumn{4}{|c|}{ Age (months) } & \multirow{2}{*}{\multicolumn{2}{|c|}{$\begin{array}{c}\text { Total } \\
(n=176)\end{array}$}} & \multirow{2}{*}{\multicolumn{2}{|c|}{ Test of significance }} \\
\hline & \multicolumn{2}{|c|}{$\begin{array}{l}24-<48 \\
(n=114)\end{array}$} & \multicolumn{2}{|c|}{$\begin{array}{c}48-60 \\
(n=62)\end{array}$} & & & & \\
\hline & Mean & SD & Mean & SD & Mean & SD & $\mathbf{t}$ & P-value \\
\hline Total energy (kcal) & 874.3 & 220.9 & 971.0 & 220.5 & 908.3 & 224.9 & 2.77 & $0.006^{*}$ \\
\hline Carbohydrate (g) & 123.8 & 31.9 & 135.5 & 30.9 & 127.9 & 32.0 & 2.34 & $0.020^{*}$ \\
\hline Total protein (g) & 28.1 & 8.5 & 31.2 & 8.2 & 29.2 & 8.5 & 2.33 & $0.013^{*}$ \\
\hline Animal protein $(\mathrm{g})^{\mathrm{a}}$ & 11.7 & 9.1 & 13.9 & 8.0 & 12.5 & 8.8 & 1.53 & 0.126 \\
\hline Plant protein (g) & 16.2 & 5.2 & $17 \cdot 3$ & 4.6 & 16.6 & 5.1 & 1.35 & 0.178 \\
\hline Total fat (g) & 29.6 & 12.4 & 33.8 & 12.8 & 31.1 & 12.6 & 2.12 & $0.035^{*}$ \\
\hline Animal fat $(g)^{\mathbf{b}}$ & 10.8 & 8.2 & 13.7 & 9.3 & 11.8 & 8.7 & 2.15 & $0.032 *$ \\
\hline Plant fat (g) & 18.8 & 10.6 & 20.0 & 12.7 & 19.2 & 11.4 & 0.67 & 0.498 \\
\hline Calcium (mg) & 312.0 & 188.1 & 300.2 & 165.4 & 307.8 & 180 & 0.41 & 0.680 \\
\hline Zinc (mg) & 4.2 & 1.4 & 4.6 & 1.2 & 4.4 & 1.4 & 1.86 & 0.063 \\
\hline Total iron (mg) & 6.7 & 2.4 & 7.3 & 2.8 & 6.9 & 2.6 & 1.35 & 0.179 \\
\hline \multirow[t]{2}{*}{$\%$ animal foods energy to total energy } & 16.1 & 11.8 & 18.6 & 11.7 & 17.05 & 11.8 & 1.13 & 0.257 \\
\hline & & & & & & & $\mathbf{z}$ & P-value \\
\hline Animal iron $(\mathrm{mg})^{\mathrm{c}}$ & 1.2 & 1.9 & 1.0 & 1.0 & 1.1 & 1.6 & 0.56 & 0.574 \\
\hline Plant iron (mg) & 6.1 & 5.3 & 6.2 & 2.7 & 6.1 & 4.5 & 1.37 & 0.168 \\
\hline Vitamin A ( $\mu$ g RE) & 169.3 & 333.2 & 148.7 & 153.9 & 162 & 283 & 0.58 & 0.561 \\
\hline
\end{tabular}

${ }^{a}$ Ratio of animal protein to total protein intake $42.8 \%$

${ }^{\text {b}}$ Ratio of animal fat to total fat intake $37.9 \%$.

'Ratio of animal iron to total iron intake15.9\%.

$t=$ independent samples $t$-test.

$z=$ Mann-Whitney test. 
Table 2 Nutrient density ratio according to age among preschool children in Gaza city, 2018

\begin{tabular}{lcccccc}
$\begin{array}{l}\text { Nutrient } \\
\text { density ratio }\end{array}$ & \multicolumn{3}{c}{ Age (months) } & \multicolumn{2}{c}{ Total } \\
& $\begin{array}{l}\mathbf{2 4}-<\mathbf{4 8} \\
(\mathbf{n = 1 4 )}\end{array}$ & \multicolumn{2}{c}{$\begin{array}{c}\mathbf{4 8 - 6 0} \\
(\mathbf{n = 6 2})\end{array}$} & & \\
& Mean & SD & Mean & SD & Mean & SD \\
\hline Protein & 13.0 & 3.1 & 13.0 & 2.8 & 13.0 & 3.0 \\
Fat & 29.6 & 8.5 & 30.7 & 7.8 & 30.0 & 8.3 \\
Carbohydrate & 57.3 & 9.1 & 56.3 & 8.1 & 56.9 & 8.7 \\
\hline
\end{tabular}

dietary intake, and the deficiency was slightly greater among the older age group (Table 3). Iron, carbohydrate, zinc and protein also showed dietary deficiency, generally the values for these were under $50 \%$, except for iron deficiency in the older age group (53.2\%). For protein, the level of deficiency was under $10 \%$.

\section{Macro- and micronutrient adequacy by locality}

Table 4 describes the proportion of preschool children in the sample whose dietary intake for a given nutrient was less than $75 \%$ of the RDA, thus defining the extent of macro- and micronutrient deficiency according to locality.

The energy intake deficiency ( $<75 \%$ of RDA) among the preschool children in this study was greater in urban (90.5\%) and rural $(90.0 \%)$ areas compared with refugee camp children $(85.0 \%)$ (Table 4). However, the greatest prevalence of vitamin A intake deficiency was among the refugee camp children (95.0\%), followed by urban children (88.1\%). The highest prevalence of calcium intake deficiency was recorded in the children in the rural area $(76.7 \%)$, closely followed by the urban area children (73.8\%). Generally, deficiency levels for iron, carbohydrate and zinc were $<50 \%$, although iron deficiency was $63.3 \%$ among the rural children. The proportion showing protein deficiency was $\leq 10 \%$, and all children in the refugee camp met their protein adequacy. Adequate dietary intake among the children was the worst in the rural area relative to the other locations for all nutrients except vitamin A: the refugee camp shower the worst deficiency for this (Table 4).

\section{Discussion and conclusion}

The aim of this study was to assess nutrient intakes and adequacy among preschool children in Gaza, which has been under blockade for more than 13 years. The findings show that energy had the highest dietary deficiency among the studied preschool children, followed by vitamin $\mathrm{A}$ intake. There was a dramatic deterioration in macro- and micronutrient adequacy, especially in the rural area. The finding show a higher deficiency rate for energy $(90 \%)$ than was found in previous local studies $(13,14)$. Jildeh's study pointed out that, among adolescents of East Jerusalem, $55.6 \%$ of boys and $64.8 \%$ of girls had energy deficiency (13) whereas the 2009 survey by Abdeen et al. in Palestine found that the energy intake deficiency among children aged 3-9 years was about $66 \%$ (14).
The data for vitamin A in this study indicates a higher deficiency (overall 86.9\%) than was found in a 2015 study in Palestine in which the reported prevalence of intake inadequacy was $63 \%$ among children (15). The higher dietary intake deficiency in the current study may reflect the geographical difference in the implementation of the studies between the Gaza Strip and the West Bank: the worst deterioration in energy and vitamin A intakes in the Gaza Strip may be attributed to the continuous restrictions and blockade by Israel on Gaza and the difficult economic situation over the past 14 years. Additionally, some differences may be related to differences in the assessment methods used, the age groups studied and the different sample sizes.

The finding for iron deficiency in this study is in line with the study of Mirmiran, who reported the prevalence of iron deficiency anaemia to be a major public health problem in the Eastern Mediterranean countries, and the highest rates of deficiency were among preschool children (16). It is worth mentioning that more than half the studied students had zinc intake deficiency and this result is higher than the values found in other recent regional and local studies $(17,18)$.

Animal iron intake was lower than plant source iron intake among the children in this study, which is compatible with the 2017 findings of Hwalla et al. for the Middle East (17). These findings could be explained by a higher consumption of protein from plant sources, especially bread, which is considered the main staple food for the people of Palestine.

Findings for nutrient deficiency in the rural area, which was the worst locality for the nutritional status of preschoolers in the Gaza Strip, corresponds with the results of previous reports from the Israeli human rights group Gisha (19) and from Radi et al. (20). These findings were confirmed by previous studies $(21,22)$ and in the Guardian newspaper's report entitled "Israel used 'calorie count' to limit Gaza food during blockade, critics claim" (19). In the same context, the findings relating to nutrient

\begin{tabular}{|c|c|c|c|}
\hline \multicolumn{4}{|c|}{$\begin{array}{l}\text { Table } 3 \text { Proportion of macro- and micronutrient deficiency } \\
\text { (i.e. below the } 75 \% \text { recommended dietary allowance level of } \\
\text { dietary intake for a given nutrient) distributed by age among } \\
\text { preschool children in Gaza city, } 2018\end{array}$} \\
\hline \multirow[t]{4}{*}{ Nutrient } & \multicolumn{2}{|c|}{ Age (months) } & \multirow{3}{*}{$\begin{array}{c}\text { Total } \\
(n=176)\end{array}$} \\
\hline & $\begin{array}{l}24-<48 \\
(n=114)\end{array}$ & $\begin{array}{c}48+ \\
(n=62)\end{array}$ & \\
\hline & \multicolumn{2}{|r|}{ Deficiency } & \\
\hline & $\%$ & $\%$ & $\%$ \\
\hline Energy & 87.7 & 93.5 & 89.8 \\
\hline Vitamin A & 86.0 & 88.7 & 86.9 \\
\hline Calcium & 69.3 & 80.6 & 73.3 \\
\hline Iron & 43.9 & 53.2 & 47.2 \\
\hline Carbohydrate & 24.6 & 11.3 & 19.9 \\
\hline Zinc & 17.5 & 16.1 & 17.0 \\
\hline Protein & 2.6 & 8.1 & 4.5 \\
\hline
\end{tabular}




\begin{tabular}{|c|c|c|c|}
\hline \multirow[t]{3}{*}{ Nutrient } & \multicolumn{3}{|c|}{ Locality } \\
\hline & $\begin{array}{c}\text { Urban } \\
(n=126)\end{array}$ & $\begin{array}{c}\text { Refugee } \\
\text { camp } \\
(n=20)\end{array}$ & $\begin{array}{c}\text { Rural } \\
(n=30)\end{array}$ \\
\hline & $\%$ & $\%$ & $\%$ \\
\hline Energy & 90.5 & 85.0 & 90.0 \\
\hline Vitamin A & 88.1 & 95.0 & 76.7 \\
\hline Calcium & 73.8 & 65.0 & 76.7 \\
\hline Iron & 46.0 & 30.0 & 63.3 \\
\hline Carbohydrate & 19.8 & 10.0 & 26.7 \\
\hline Zinc & 15.1 & 20.0 & 23.3 \\
\hline Protein & 4.0 & 0.0 & 10.0 \\
\hline
\end{tabular}

deficiency intake in the present study are higher than those found in a regional study in Saudi Arabia (23). Also, it is notable that most of the macro- and micronutrient adequacy intake reported in this study showed greater deterioration than found in previous research (21) and in a report from the World Food Programme (8).

The findings in this study are in line with the results of the recent survey from UNICEF, Save the Children and the World Food Programme (24), which revealed that the poor food consumption score was worse $(23 \%)$ compared with national results, which showed that $7 \%$ of households in the Gaza Strip had a poor food consumption score in 2016, reflecting the worsening situation among the assessed populations. The current coping strategies of the population show a deterioration in the diet in terms of variety and frequency. The disaggregation of nutrientrich foods shows concerns around the consumption of iron-rich foods, and partially around vitamin A-rich foods. It is reasonable to assume that the deterioration in nutritional status in the Gaza Strip is a result of the Israeli blockade and tightening of restrictions on the movement of people and goods, as reported in a number of international, regional and local reports $(22,24,25)$.

The worst results in this study could be explained by a new World Bank report, which shows that the economy in Gaza is collapsing, suffering from a decade long blockade and a recent drying up of liquidity, with aid flows no longer enough to stimulate growth. While the blockade is the core issue, a combination of factors has more recently impacted the situation in Gaza, including the decision of the Palestinian Authority to reduce the monthly payments to the area, the winding down of monetary aid per year from the US Government aid programme, and the cuts to the United Nations Relief and Works Agency programme (26).

This study is strongly recommended along with other national, regional and local reports that strongly call for the need to lift the siege imposed by the Israeli occupation forces on the Gaza Strip (27-29). They emphasize the need for a balanced approach to the situation in Gaza that combines an immediate crisis response to ensure the continuation of key services such as energy, water, education and health. These basic services are critical for people's livelihoods and for the economy to function. Another urgent need is to increase household purchasing power to enable a return to basic economic activity, which will contribute positively to the health and nutritional status of people in the Gaza Strip, particularly the vulnerable groups.

Every study has limitation and there are 2 major limitations in this study that could be addressed in future research. First, the study focused on selecting a subsample from the total calculated sample size; this yielded a small sample size in order to avoid using up too many resources, e.g. human, time and financial resources, and to address the issue in a relatively short space of time. Although, there is nothing wrong with conducting well-designed small studies, addressing more-targeted children and governorates in the Gaza Strip is recommended in future studies.

The second limitation concerns accessing the targeted households without a stable means of transportation to collect the required data and navigate between districts and regions. Accordingly, it is recommended that any future field study should provide dedicated transportation for the research teams and for the purpose of visits and data collection through the fieldwork, with transportation reserved for this purpose.

Funding: None.

Competing interests: None declared.

\section{Apports nutritionnels et adéquation des nutriments chez les enfants d'âge préscolaire sous blocus à Gaza, Palestine \\ Résumé}

Contexte: Après 13 ans de blocus et de fermeture, la malnutrition est devenue un risque significatif pour la santé des habitants les plus jeunes de Gaza. Selon de récentes enquêtes nationales, les Palestiniens sont confrontés à une double charge de malnutrition et connaissent de très faibles niveaux de minéraux et de vitamines essentiels.

Objectifs : La présente étude avait pour objectif d'évaluer l'adéquation de l'apport en nutriments chez les enfants d'âge préscolaire et d'estimer les carences alimentaires et nutritionnelles dans la Bande de Gaza. 
Méthodes: La présente enquête transversale, communautaire et auprès des ménages a été réalisée à Gaza en utilisant des rappels alimentaires de 24 heures pour évaluer l'apport en nutriments et leur adéquation chez 176 enfants âgés de deux à cinq ans.

Résultats: D'après la carence en nutriments par rapport à l'apport alimentaire $[<75 \%$ de l'apport journalier recommandé (AJR) ], l'énergie présente le niveau de carence le plus élevé $(89,8 \%$ ) chez les enfants étudiés, suivi de l'apport en vitamine A (86,9\%). Environ trois quarts (73,3\%) des enfants étudiés consomment moins que l'AJR pour le calcium, 47,2\% de moins pour le fer, $20 \%$ de moins pour l'apport alimentaire en glucides et $17 \%$ de moins pour le zinc, respectivement.

Conclusions: L'apport en nutriments chez les enfants d'âge préscolaire de la Bande de Gaza montre une détérioration spectaculaire des carences en macro- et micronutriments, en particulier dans les zones rurales. Bien que les résultats de la présente étude soient conformes aux rapports précédents, ils ont révélé une détérioration plus importante que les études locales précédentes.

$$
\begin{aligned}
& \text { مدخول المغذيات و كفايتها بين الأطفال الذين هم دون سن المدرسة ويعيشون تحت الحصار في مدينة غزة، فلسطين } \\
& \text { سمير راضي ماضي } \\
& \text { الخالاصة }
\end{aligned}
$$

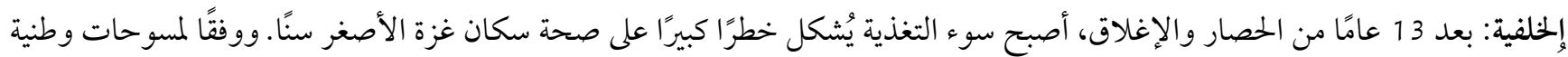

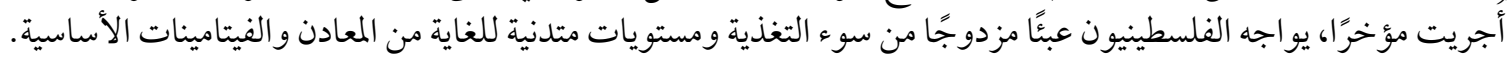

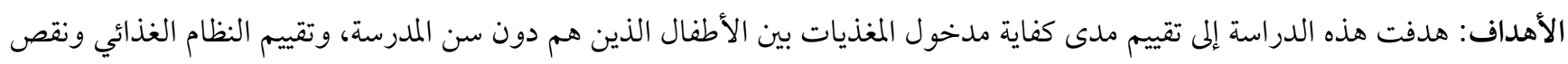

$$
\begin{aligned}
& \text { مخزون المغذيات في قطاع غزة. } \\
& \text { طرق البحث: أُجري هذا المسح المجتمعي المقطعي للأسر في غزة باستعر اض النظام الغذائي على مدار } 24 \text { ساعة لتقييم مدخول إنى المغذيات وكفايتها }
\end{aligned}
$$

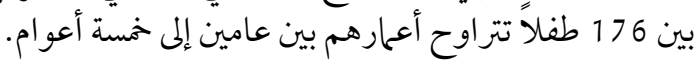

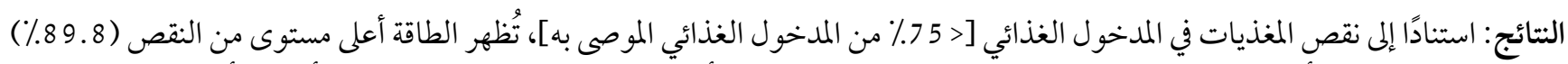

$$
\begin{aligned}
& \text { من المدخول الغذائي الموصى به للزنك. } \\
& \text { بالدر اسات المحلية السابقة. }
\end{aligned}
$$

\section{References}

1. Population, housing and establishments census 2017: main indicators by type of locality. Ramallah: Palestinian Central Bureau of Statistics; 2019.

2. WFP State of Palestine country brief; operational context. Jerusalem: World Food Programme; 2018 (https://www.un.org/unis$\mathrm{pal} /$ document/wfp-palestine-country-brief-may-2018/, accessed 20 December 2020).

3. Situation report; occupied Palestinian territory, Gaza; 01-30 June 2019. Gaza: Health Cluster, World Health Organization; 2019 (https://www.un.org/unispal/wp-content/uploads/2019/07/WHOSITREP_111019.pdf, accessed 20 December 2020).

4. State of Palestine appeal. Jerusalem: UNICEF; 2019 (https://www.unicef.org/appeals/state_of_palestine.html, accessed 27 November 2020).

5. Hope for a healthy future: combatting malnutrition in Gaza. London: Medical Aid for Palestinians; 2018 (https://www.map.org. uk/news/archive/post/786-hope-for-a-healthy-future-combatting-malnutrition-in-gaza, accessed 27 November 2020).

6. Food assistance for the food-insecure populations in the West Bank and Gaza Strip. Standard project report 2016. Jerusalem: World Food Programme in Palestine; 2017 (https://docs.wfp.org/api/documents/918d89116fo945259485a047cdb19345/download/?_ga=2.259461130.1458071756.1505152127-712708814.1497636239, accessed 20 December 2020).

7. West Bank and Gaza, report to the Ad Hoc Liaison Committee. March 9, 2018. Washington: International Monetary Fund; 2018.

8. Executive Board. State of Palestine country strategic plan (2018-2022). Rome: World Food Programme; 2017 (WFP/ EB.2/2017/7-A/4; https://documents.wfp.org/stellent/groups/public/documents/eb/wfp293161.pdf, accessed 27 November 2020). 
9. Hammond, K. Assessment: dietary and clinical data. In: Mahan LK, Escott-Stump S. Krause's food and nutrition, 12th ed. St. Louis: Saunders/Elsevier; 2008:383-409.

10. Abdeen Z, Greenough,G, Shahin M, Tayback M. Nutritional assessment of the West Bank and Gaza Strip. Jerusalem: CARE International; 2002.

11. Food composition tables for Egypt, 2nd ed. Cairo: National Nutrition Institute; 2006.

12. National Research Council \& National Academy of Sciences. Recommended dietary allowances. 1oth ed. Dietary reference intakes for energy, carbohydrate, fiber, fat, fatty acids, cholesterol, protein, and amino acids (macronutrients). Washington DC: National Academies Press; 2005.

13. Jildeh C, Papandreou C, Abu Mourad T, Hatzis C, Kafatos A, Qasrawi R, et al. Assessing the nutritional status of Palestinian adolescents from East Jerusalem: a school-based study 2002-03. J Trop Pediatr. 2011 Feb;57(1):51-8. doi:10.1093/tropej/fmq042

14. Abdeen Z, Allen L, Carriquiry A, Dary O, Qaswari R, Ramlawi A, et al., Determining the dietary pattern and biochemical markers among women and children in Hebron and Gaza City. Jerusalem: Al-Quds University; 2010 (http://www.azzproject.org/pdf/Dietary_SURVEY.pdf, accessed 20 December 2020).

15. Abdeen Z, Ramlawi A, Qaswari R, Alrub AA, Dary O, Rambeloson Z, et al. Predicted efficacy of the Palestinian wheat flour fortification programme: complementary analysis of biochemical and dietary data. Public Health Nutr. 2015 Jun;18(8):1358-68. doi:10.1017/S1368980014001554

16. Mirmiran P, Golzarand M, Serra-Majem L, Azizi F. Iron, iodine and vitamin a in the middle East; a systematic review of deficiency and food fortification. Iran J Public Health. 2012;41(8):8-19. PMID:23113219

17. Hwalla N, Al Dhaheri AS, Radwan H, Alfawaz HA, Fouda MA, Al-Daghri NM, et al. The prevalence of micronutrient deficiencies and inadequacies in the Middle East and approaches to interventions. Nutrients. 2017 Mar 3;9(3):229. doi:10.3390/nu9030229

18. Wahaidi AA, Abed Y, Sarsour A, Turban M. The adolescent's quality of life in the Gaza Strip: nutritional and psychological risk factors. Food Nutrit Open Access. 2018;1. doi:10.31021/fnoa.20181105.

19. Associated Press, in Jerusalem. Israel used 'calorie count' to limit Gaza food during blockade, critics claim. The Guardian, Wed 17 Oct 2012 (https://www.theguardian.com/world/2012/oct/17/israeli-military-calorie-limit-gaza, accessed 27 November 2020)..

20. Radi SM, El-Sayed NA, Nofal LM, Abdeen ZA. Ongoing deterioration of the nutritional status of Palestinian preschool children in Gaza under the Israeli siege. Eastern Mediterr Health J. 2013;19(3): 234-41. PMID:23879074

21. Strategic review of food and nutrition security in Palestine, 2017. Ramallah: Palestine Economic Policy Research Institute (MAS); 2017 (https://docs.wfp.org/api/documents/WFP-0000022569/download/, accessed 27 November 2020).

22. UN Humanitarian Coordinator. The closure of the Gaza Strip puts at risk the health of people in Gaza and undermines the functioning of the health care system. New York: UN, Association of International Development Agencies; 2010.

23. Allam AR, Taha IM, Al-Nozha OM, Sultan IE. Nutritional and health status of medical students at a university in Northwestern Saudi Arabia. Saudi Med J. 2012 Dec;33(12):1296-303. PMID:23232677

24. The Nutrition Working Group, occupied Palestinian territory. Report of the multi-sectorial nutrition assessment conducted in the vulnerable areas of the Gaza Strip, occupied Palestinian territory, from October 15 to 31, (2018). Save the Children, UICEF, World Food Programme; 2018 (https://www.unicef.org/sop/media/1091/file, accessed 27 November 2020).

25. Joint rapid food security survey in the occupied Palestinian Territory, 2008. Rome: Food and Agriculture Organization of the United Nations, World Food Programme, United Nations Relief and Works Agency for Palestine Refugees in the Near East; 2008 (https://documents.wfp.org/stellent/groups/public/documents/ena/wfp181837.pdf, accessed 27 November 2020).

26. Trew B. Gaza's economy "collapsing” due to Israeli blockade and massive funding cuts, World Bank warns. The Independent, 25 September 2018 (https:/www.independent.co.uk/news/world/middle-east/gaza-economy-palestinian-world-bank-israel-west-bank-a8554466.html, accessed 27 November 2020).

27. United Nations Country Team in the occupied Palestinian territory. Gaza ten years later. New York: United Nations; 2017 (https://www.un.org/unispal/document/gaza-ten-years-later-un-country-team-in-the-occupied-palestinian-territory-report/, accessed 27 November 2020).

28. Fourth Geneva Convention relative to the protection of civilian persons in time of war of 12 August 1949. Article 59: Relief I.Collective relief. New York: United Nations; 1950 (https://www.un.org/en/genocideprevention/documents/atrocity-crimes/ Doc.33_GC-IV-EN.pdf, accessed 27 November 2020).

29. Detailed needs assessment (DNA) and recovery framework for Gaza reconstruction. Palestine: Ministerial Committee for the Reconstruction of Gaza; 2015 (http://www.ldf.ps/documentsShow.aspx?ATT_ID=21974, accessed 12 December 2020). 